\title{
HOMERO E O MUNDO VEGETAL
}

$\begin{aligned} \text { Maria de Fátima Silva* } & * \text { Professora } \\ & \text { Catedrática, } \\ & \text { Instituto de Estudos } \\ & \text { Clássicos, Centro de } \\ \text { Recebido em: 30/09/2019 } & \text { Estudos Clássicos } \\ \text { Aprovado em: 21/10/2019 } & \text { e Humanísticos, } \\ & \text { Universidade de } \\ & \text { Coimbra. } \\ & \text { fanp13@gmail.com }\end{aligned}$

RESUMO: Homero é reconhecido, séculos mais tarde, por Teofrasto como uma fonte a considerar em matéria botânica e algumas referências concretas lhe são feitas na História das plantas. Mas a importância desta componente, sobretudo na Odisseia, vai além de um propósito informativo sobre a relação entre as plantas e os diversos ambientes referidos no poema; a construção literária do nóstos de Ulisses passa também pela exploração simbólica das paisagens diversas que vai cruzando.

PALAVRAS-CHAVE: Odisseia; paisagens; espécies vegetais; nóstos; anagnórisis.

\section{PLANTS IN HOMER}

ABSTRACT: Homer is considered, some centuries later, by Theophrastus as a source in a botanical perspective and some concrete quotations are included in the History of plants. But the importance of this element, mainly in the Odyssey, is deeper than a mere information about the relation between plants and the different landscapes mentioned in the poem; the literary structure of Odysseus' nostos also explores the various symbolic landscapes he crosses.

KEYWORDS: Odyssey; landscapes; vegetarian species; nostos; anagnorisis.

$O^{2}$ e é certo que a Botânica como ciência surgiu no mundo grego, já no séc. IV a.C., no Liceu de Aristóteles e pela mão de Teofrasto, não é menos verdade que as referências insistentes que são feitas, pelo autor de História das plantas, a autoridades que o precederam demonstram o empenho e a atenção que o conhecimento 
e manipulação das plantas vinham tendo ao longo de séculos. ${ }^{1} \mathrm{O}$ grande mérito daquele que se pode considerar 'o pai da Botânica' terá sido, então, antes de mais a compilação e a abordagem crítica de opiniões que proliferavam na época, e sobretudo a tentativa de sistematização do saber a respeito das plantas, das suas condições de vida, da sua relação com o ecossistema e da sua utilidade de há séculos acumulado. ${ }^{2}$

Ora, entre as fontes tradicionais sobre a matéria contam-se os testemunhos prestados pelos Poemas Homéricos, como a remissão mais antiga para o conhecimento de certas espécies vegetais e suas caraterísticas. ${ }^{3}$ Estes são casos específicos, em que o nome de Homero é identificado por Teofrasto e que remetem, portanto, para passos épicos concretos. Mas, além deles, é evidente o interesse e conhecimento que o autor dos Poemas Homéricos revela sobre o mundo vegetal, abordado com insistência e sob diversas perspetivas. A deslocação de Gregos para uma paisagem asiática - a região de Ílion - na Ilíada, e, sobretudo, a itinerância de Ulisses por territórios da grande área mediterrânica, na Odisseia, são contextos que fomentam a descrição de paisagens como enquadramento para os acontecimentos da guerra, primeiro, e, depois, do nóstos. A geografia envolvida é ampla, grega e exterior às fronteiras do mundo helénico, a configuração dos terrenos variada - ilhas, montanhas e planícies -, e,

\footnotetext{
${ }^{1}$ Apesar de já ter havido, em época anterior, algumas abordagens das questões suscitadas pelas plantas - nos tratados hipocráticos, ou por nomes avulsos de interessados pelo seu poder curativo, como Díocles de Caristo, por exemplo -, tem sido reconhecido a Teofrasto o mérito de ter dado os primeiros passos no sentido de fazer do estudo das plantas uma verdadeira ciência e, nessa medida, ser o verdadeiro criador da Botânica. Alguns autores literários, como Hesíodo ou Xenofonte, mesmo se interessados pela agricultura, não tentaram uma classificação das plantas, a grande novidade de Teofrasto (sobre os autores gregos que se interessaram pela agricultura, cf. Columela, Sobre a agricultura 1.1.7; e sobre a excecionalidade de Teofrasto que, mais do que aos agricultores, foi útil aos filósofos e mesmo aos médicos, ou seja, à ciência propriamente dita, cf. Varrão, Sobre a agricultura 1.5.1-2). Entre os nomes citados por Teofrasto contam-se Trabalhos e Dias de Hesíodo (3.7.6, 7.13.3, 8.1.2); em 3.1.4, Anaxágoras, Diógenes de Apolónia e Clidemo, focados sobretudo no estudo geral da phýsis. Outros nomes, porém, parecem contribuir para a reflexão sobre questões mais práticas, como o de Andrócion (2.7.2-3) no que se refere à cultura das árvores. A Magna Grécia, pelos seus naturais contactos políticos e culturais com a Hélade, está incluída no circuito de investigação útil e respeitável. É o caso de Menestor (1.2.3, 5.3.4, 5.9.6), um contemporâneo de Empédocles, cujas opiniões Teofrasto em geral aprova ou pelo menos considera. Respeitado é também o nome de Hípon de Samos (1.3.5, 3.2.2). 2 Ao enumerar as inovações e o valor da atitude científica de Teofrasto, Thanos (2005, p. 23) sintetiza: "Teofrasto atua na ciência das plantas de um modo magistral e científico: citando, de forma crítica, o saber acumulado pela Antiguidade Clássica sobre botânica; processando informação fornecida por informadores competentes, por profissionais ou simplesmente por gente comum; e usando a experiência pessoal colhida na sua própria observação e em viagens realizadas".

${ }^{3}$ Cf. Teofrasto, História das plantas 9. 15. 1, a propósito do poder medicinal de espécies egípcias, e 9. 15. 7, onde é referida a móly. Vide infra. Haller (2017, p. 13) valoriza a evidência de que a Odisseia é muito mais rica em descrições de paisagens do que a Ilíada e subtil na sua idealização; justifica-a pelo distanciamento entre o poeta e o auditório, em relação ao universo temporal, social e cultural que está a ser retratado.
} 
em consequência, a vegetação diversa e mais ou menos familiar, já significativa da elevada fitodiversidade mediterrânica. A realidade mistura-se com a convenção mítica, na medida em que as paisagens habitadas por homens alternam com aquelas que deuses ou seres fantásticos ocupam. Dentro desta variedade literária de situações, não deixa de haver, no entanto, uma abordagem do assunto 'flora' que toca, mesmo se de forma ocasional, o que viriam a ser bases metodológicas para a futura botânica.

Ir além das referências expressamente feitas por Teofrasto a um Homero conhecedor de plantas exóticas coloca diversas interrogações que se podem mostrar relevantes para a própria interpretação dos Poemas e das questões que se colocam sobre a sua autoria: ${ }^{4}$ que veracidade ou razoabilidade haverá na relação que Homero estabelece entre a geografia dos lugares, a sua flora e a sua cultura? Será que a convenção poética se sobrepõe à descrição objetiva das regiões, das condições do terreno e da compatibilidade com as espécies descritas? Teria o poeta um conhecimento efetivo dos espaços e da vegetação que descreve? A ser direto o contacto do poeta com as espécies referidas, em que território ou territórios se situaria o autor que convencionalmente se designa por Homero? Uma comparação com as conclusões estabelecidas por Teofrasto sobre as condições naturais exigidas por cada espécie vegetal e sobre a sua distribuição de acordo com os terrenos e com os climas poderá, de alguma forma, contribuir para uma avaliação deste elemento narrativo dos Poemas Homéricos e para as questões de autoria e contexto que lhes estão adjacentes.

\section{O CONVENCIONALISMO POÉTICO DAS PAISAGENS}

\section{As ilhas}

Poder-se-ia estabelecer, como uma primeira distinção básica nos Poemas Homéricos,

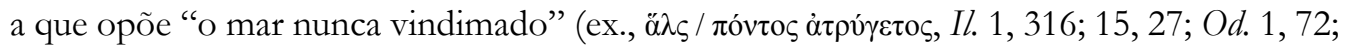
$2,370 ; 13,418)$ à "terra dadora de cereais" ou à "planície dadora de trigo" (

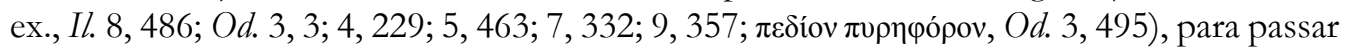
depois à consideração, no que toca ao solo, de diversas regiões e geografias.

$\mathrm{E}$, reconhecendo a maior visibilidade dada às descrições da paisagem na Odisseia, vejamos como, no itinerário de Ulisses, se multiplicam as ilhas que têm nesse poema um tratamento peculiar. Habitadas por criaturas míticas, como Calipso e Circe, ou por povos já bem conhecidos à altura da guerra de Troia, como Ítaca ou Creta, elas integram um vasto território insular cujas caraterísticas essenciais são, globalmente, harmoniosas. Assim

\footnotetext{
${ }^{4}$ Lourenço (2018, p. 90-191) acentua a raridade com que descrições de paisagens ocorrem na literatura grega, sobretudo arcaica (não esqueçamos a dimensão que tais descrições vieram a ter num autor clássico como Heródoto). Ao tratar o passo do canto $\mathrm{V}$ da Odisseia referente à ilha de Calipso como "uma famosa exceção", Lourenço mesmo assim subvaloriza a presença que este tipo de descrição tem nos Poemas Homéricos, que se estende, como veremos, a outros casos igualmente significativos. ${ }^{5}$ As traduções usadas dos Poemas Homéricos, salvo algumas alterações na fixação dos nomes das espécies vegetais, são as de Lourenço $(2005,2018)$.
} 
todas elas por convenção tendem a ser, como a ilha de Calipso, "arborizadas" (sendo vĩ $\sigma o \varsigma$ $\delta \varepsilon v \delta \rho \eta ́ \varepsilon \sigma \sigma \alpha$ uma expressão que convencionalmente as designa, cf. Od. 1, 51), ou, como a

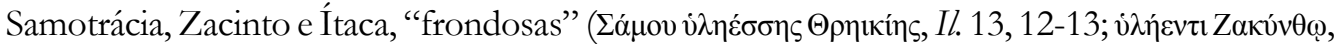

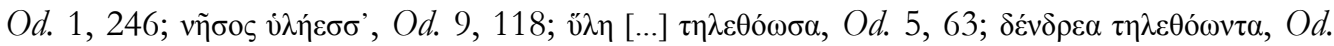
13, 196). ${ }^{6}$ Mas, para além destes epítetos genéricos, o poeta passa, em alguns casos, a uma identificação das espécies que constituem a floresta insular. Aos navegantes que aportaram à ilha de Calipso ${ }^{7}$ chegou, provindo da caverna da deusa, o aroma da fogueira feita com espécies locais, "do cedro e da thuía" (Od. 5, 59-60). ${ }^{8}$ Ora, os cedros que Teofrasto conhece - "o

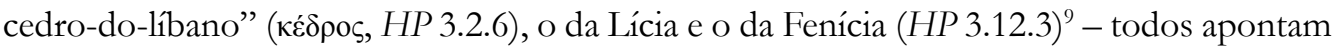
para uma origem asiática, ${ }^{10}$ ainda que depois dispersos pela bacia do Mediterrâneo; por seu lado a thuia, bem conhecida em regiões gregas (o norte do Peloponeso, a Arcádia), revela preferência "pelas altas montanhas e sítios frios" (HP 4.1.3), colaborando na construção

${ }^{6}$ A predominância da floresta como caraterística das ilhas é também abonada por inúmeras referências feitas por Teofrasto, em História das plantas; cf. e. g., 4.1.4, 4.7.4, 4.7.7-8, 5.8.2. Por outro lado, Baumann (1984, p. 10), ao recordar a aspereza da paisagem grega, escassamente florestada sobretudo depois de séculos de devastação com vista ao provimento das necessidades humanas, justifica indiretamente o contraste estabelecido com as ilhas. Não sem deixar de precisar: "A flora especificamente mediterrânica das ilhas e das regiões costeiras muda-se em flora continental nas montanhas."

${ }^{7}$ Lourenço (2018, p. 64-5), a propósito de Od. 1, 50 - "ilha rodeada de ondas, onde fica o umbigo do mar" - detém-se sobre a localização da ilha de Calipso ( $O d .1$, 85, designada por Ogígia). Sem deixar de referir as múltiplas identificações que antigos e modernos lhe foram atribuindo - "Creta, Gozo, Malta e até Gibraltar, além da ilha da Madeira" -, Lourenço usa Od. 5.272-277 e as informações astronómicas que dá, para defender a localização ocidental da ilha. Boardman (2003, p. 25), por seu lado, não deixa de assinalar, como excessiva, a localização das aventuras de Ulisses para além das Colunas de Héracles.

${ }^{8}$ Miles (2016, p. 185) associa a sensação de aromas - como o do incenso e de diferentes espécies florestais, muitas delas acessíveis no local - com a aproximação de um lugar sagrado. Esta é uma simbologia também apropriada à aproximação da gruta de Calipso. Haller (2007, p. 81) concretiza na ilha da ninfa o essencial na experiência do nóstos: se o herói resiste ao atrativo de "um paraíso luxuriante" e aos encantos perfeitos de uma ninfa, está provada a resiliência e garantia de regresso, que nenhuma tentação pode deter. Atentemos ainda na menção, implícita neste quadro dos odores provocados pelo uso das madeiras locais, à desflorestação para diversas utilidades de que desde logo a ilha mítica de Calipso é exemplo.

${ }^{9}$ Informa Teofrasto em 3.12.3: "Há quem diga que o kédros tem duas variantes, a da Lícia e a da Fenícia, enquanto, segundo outras opiniões, só tem uma forma. [...] Há mesmo quem os não distinga pelo nome, e chame a ambos 'cedro', embora a um designe por 'cedro' e a outro por 'oxicedro"'.

${ }^{10}$ A área nativa do típico cedro-do-líbano são as montanhas do NE da costa mediterrânica: desde o ocidente das montanhas de Taurus, no sudoeste da Turquia, às montanhas do Líbano, com uma zona extensa na província de Tokar (Turquia) junto ao Mar Negro. Lembremos que a outra menção a esta mesma espécie em Il. 24, 192 se refere ao palácio de Príamo. Haller (2007, p. 92-3) alerta para que "a relativa escassez e valor desta madeira em Homero sugere que o seu uso para queimar [...] possui conotações religiosas". Por outro lado, a associação do cedro com o incenso confirma o tom orientalizante do local e dá a Ogígia tonalidades de um paraíso asiático. 
imaginária da ilha habitada por Calipso. ${ }^{11}$ Ao avançarem na direção desse cheiro, em busca de algum residente, ei-los que se deparam, junto da gruta da deusa, com um "bosque frondoso

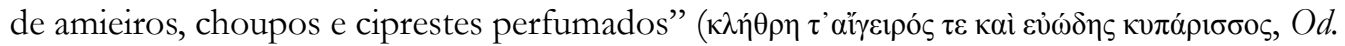
$5,64)$, numa fusão indiscriminada de espécies que denuncia uma incongruência poética; de facto, sendo umas de planície, outras de montanha, umas de terrenos húmidos (os amieiros e choupos, que são ripícolas) e outras de secos, umas de climas frios e outras de lugares mais amenos, a reunião destas espécies num só local é com certeza inaceitável do ponto de vista estritamente botânico. $\mathrm{O}$ espaço aberto junto à própria caverna de Calipso convida à integração no quadro de uma pradaria que arreda a densidade das árvores (Od. 5, 68-73). ${ }^{12}$ Uma vinha pujante, carregada de cachos, emoldurava a entrada, cercada de "suaves pradarias" ( $\lambda \varepsilon \mu \tilde{\omega} v \varepsilon \varsigma \mu \alpha \lambda \alpha \kappa o i ́)$, onde verdejavam, alimentados pela água abundante e límpida de quatro nascentes, violetas e aipo. ${ }^{13}$ No seu conjunto, a caraterização vegetal atribuída à ilha parece

${ }^{11}$ Acrescenta Lourenço (2018, p. 191), sobre a localização da ilha de Calipso: "É significativo este paraíso terrestre estar localizado no Extremo Ocidente, 'fora do alcance de qualquer viagem humana", assim identificando o caráter meramente mítico da ilha. Em consequência, deve entender-se que a descrição de um terreno imaginário segue, naturalmente, o padrão conhecido para as ilhas com que os Gregos tinham convivência direta, fosse qual fosse a sua localização. Lourenço chama ainda a atenção para a incongruência na reunião de espécies florestais com exigências distintas num mesmo terreno: “Tratando-se de um bosque imaginário, o poeta não se importou com a incongruência botânica de álamos e choupos precisarem de terreno frequentemente inundado, ao passo que os ciprestes precisam

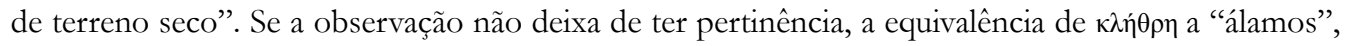
e não a amieiros, não parece correta. Teofrasto (3.3.1) associa amieiro e álamo, entre outras, como árvores que se dão tanto na montanha quanto na planície, embora afirme perentoriamente sobre as exigências do primeiro (3.14.3; cf. 4.8.1): "Dá-se em lugares húmidos e não em qualquer outro tipo de habitat". Apesar disso reconhece também, sobre o amieiro e as suas preferências ambientais (1.4.3): "No entanto, se quisermos ser rigorosos, poderemos verificar que há espécies que pertencem aos dois ambientes, que são, por assim dizer, anfíbias, como a tamargueira, o salgueiro e o amieiro". Por seu lado o choupo é referido, na História das plantas 3.3.1, como árvore de planície, particularmente associada "a locais húmidos e pantanosos" (4.1.1, 5.9.3). Por fim, sobre o cipreste, diz Teofrasto 1.9.1, "há árvores que se desenvolvem, sobretudo ou apenas, em altura (o abeto, a tamareira, o cipreste e, em geral, as de tronco único, e as que não tenham muitas raízes nem muitos ramos)"; e acrescenta (4.1.3), "Diz-se que em Creta, na montanha do Ida e nos chamados Montes Brancos, o cipreste se dá nos picos de neves eternas. De facto, esta é a espécie florestal mais abundante em toda a ilha em geral e nas montanhas". ${ }^{12}$ Excecionalmente pode ser mencionada uma ilha onde apenas existem searas e pradarias; é o caso de Dulíquion, terra de origem de Anfínomo, um dos pretendentes de Penélope $(\mathrm{Od}$. 16, 396, غ̇к

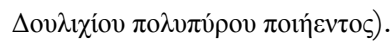

${ }^{13}$ Ao distinguir diversos tipos de aipo, justificando assim de alguma forma a menção conjunta ao aipo e à violeta na Odisseia, Teofrasto 7.6.3 serve-se do critério da localização e do cheiro e paladar: "O aipo-de-cavalo, o aipo-dos-pântanos e o aipo-da-montanha são diferentes entre si e também das variantes de cultivo. Assim, o aipo-dos-pântanos nasce junto dos riachos e nos pântanos; tem poucas folhas e não é compacto, mas tem certas semelhanças com o aipo de cultivo, no cheiro, no paladar e no aspeto. O aipo-de-cavalo tem uma folha parecida com a do aipo-dos-pântanos, mas é espessa, tem um caule alongado, e a raiz, como a do rabanete, é grossa e escura". 
compor um verdadeiro locus amoenus de conhecida tradição poética, criado sobre a variedade das espécies aleatoriamente reunidas, e sobre a alternância entre a pujança dos bosques e a delicadeza dos prados floridos, a que não falta uma tonalidade divina e mágica. ${ }^{14}$

No Canto V da Odisseia, a descrição florestal da ilha de Calipso tem ainda uma justificação evidente: a de proporcionar a madeira necessária à construção da jangada que há-de pôr o herói de novo na rota do regresso a casa, transpondo para a saga de Ulisses uma necessidade bem conhecida dos Gregos. Por isso a deusa o encaminha para o extremo da ilha, onde as árvores necessárias - "amieiros, choupos e abetos", Od. 5, 239-239b -, de grande porte e de madeira seca, ${ }^{15}$ estão ao seu dispor para esse efeito. Também neste caso das madeiras apropriadas à construção naval, porque resistentes e secas, a opção da Odisseia não conflui com a informação dada por Teofrasto: se o amieiro é uma árvore tendencialmente oca e de miolo mole, e portanto maleável, o choupo, uma espécie húmida e própria de locais pantanosos (HP 5.9.3), será inconveniente; por seu lado o abeto, como madeira fibrosa (HP 1.5.3) e friável (1.5.4), é citado por Teofrasto entre as árvores robustas (1.8.3) e portanto apropriadas para essa finalidade. Logo, no seu todo, a descrição da moldura vegetal da ilha de Calipso prima por uma intenção poética, onde as incongruências em relação a uma lógica estritamente botânica servem esse objetivo maior.

Não deixa de haver alguma semelhança, no que toca à descrição da paisagem, entre Ogígia, a ilha de Calipso, e Esquéria, a ilha habitada pelos Feaces, ${ }^{16}$ certamente justificada pelo recurso, em ambos os casos, a uma mesma convenção poética. Numa visão global, obtida ainda à distância, esta nova ilha impressionou Ulisses pelas suas "montanhas sombrias"

\footnotetext{
${ }^{14}$ Edwards (1993, p. 38) sublinha as diferentes conceções que os poemas têm do que se possa chamar 'campo', em função dos tipos de trabalho distintos que desenvolvem. Terrenos de cultivo são distintos de territórios de pastorícia, sendo os primeiros repartidos entre campos aráveis, vinhas e pomares. ${ }^{15}$ Sobre o amieiro e a sua maleabilidade, Teofrasto afirma (3.14.3): "Do amieiro há também uma só espécie. Por natureza é ereto, tem uma madeira e um coração moles, de tal maneira que as hastes finas são completamente ocas". Haller (2007, p. 94) regista oportunamente o facto de, na abordagem da ilha de Calipso, serem os aromas florestais o que o poeta valoriza, como elementos de atração, enquanto, na hora do regresso, são sobretudo a dimensão e a resistência da madeira o que é sublinhado. Desta forma, a abordagem do ambiente segue, em paralelo, as próprias etapas da aventura, passando da sedução inicial da ilha sobre um visitante que se pretende cativar, para o lado prático da satisfação das condições à continuação da viagem.

${ }^{16}$ Lourenço (2018, p. 210) retoma a discussão relativa à terra dos Feaces, tradicionalmente identificada com a ilha de Corfu, antes designada por Corcira (cf. Tucídides 1.25.4). O obstáculo a esta identificação está na proximidade entre esta ilha e Ítaca, o que torna inviáveis os tormentos de uma longa navegação experimentados por Ulisses antes de aportar à terra natal. Conclui então Lourenço, uma vez mais, que a Esquéria homérica, com as suas caraterísticas de locus amoenus, seria também um local imaginário, apesar da persistência de vários estudiosos em proporem localizações como Ischia, Cádis, Atlântida ou as Canárias. Vai no mesmo sentido a opinião de Boardman (2003, p. 32), que afirma perentoriamente que se trata "de uma cidade grega ideal". Não podemos deixar de reconhecer, de facto, que o poeta se esforça por arredar os Feaces das rotas percorridas pelos homens $(\mathrm{Od}$. 6, 8), o que contribui para a imagem de um povo fantástico.
} 


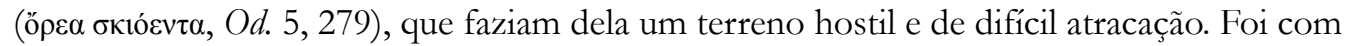
alguma persistência que o herói por fim encontrou um acesso seguro, nas margens de um rio também elas povoadas por um bosque (v̋ $\lambda \eta, O d .5,475)$ e por juncos acolhedores ( $\sigma \chi 0 i v \omega$, Od. 5, 463). ${ }^{17}$ A compatibilidade entre o espaço fluvial e a flora que o povoa é, neste caso, coerente. Do junco aquático, o poeta encontra sob dois arbustos ( $\theta$ á $\mu v o v \varsigma, ~ O d .5,476-481)^{18} \mathrm{o}$ abrigo necessário ao náufrago nesta primeira penetração da ilha. E, do mesmo modo por que procedera com a ilha de Calipso, passa de uma menção geral para a identificação de espécies

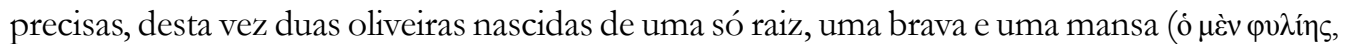
ó $\delta$ '̇̀ aíns), ${ }^{19}$ de tal modo entrelaçadas que nem os ventos nem as chuvas as penetravam. ${ }^{20} \mathrm{~A}$ opção pela oliveira quando se trata de um terreno plano, no sopé dos montes que coroam a ilha, e pela proximidade com a água, é, do ponto de vista da natureza, correta. ${ }^{21}$ Numa leitura simbólica, a oliveira, árvore sagrada de Atena, é também a manifestação concreta da presença protetora da deusa ao viajante, que se vai tornando cada vez mais explícita no poema.

Após esta impressão inicial sobre as áreas florestais que revestem os diferentes níveis da ilha, o avanço de Ulisses pelo território de Esquéria vai revelar-lhe - como antes acontecera também em Ogígia - as planícies povoadas por um outro tipo de paisagem, a

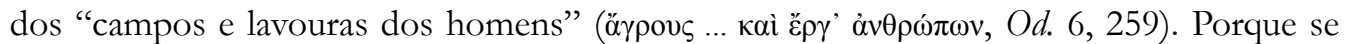

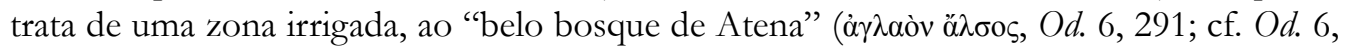

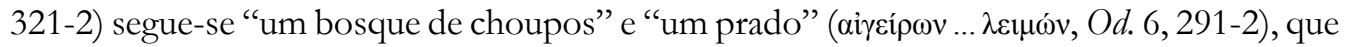
confinam com uma "propriedade e vinha viçosa” do próprio Alcínoo ( $\tau \dot{\varepsilon} \mu \varepsilon v o \varsigma \tau \varepsilon \theta \alpha \lambda \nu$ ĩ $\alpha$ ' $\dot{\alpha} \lambda \omega \eta ́$, Od. 6, 293). ${ }^{22}$ Depois da proteção, contra os elementos naturais, assegurada pela oliveira

\footnotetext{
${ }^{17}$ Cf. Teofrasto 4.8.1, que inclui os juncos entre as plantas "de rios, pântanos e lagos"; cf. ainda 4.12.1.

${ }^{18}$ Não deixa de ser curioso que o poeta da Odisseia considere a oliveira um arbusto, quando se trata reconhecidamente de uma árvore (cf. Teofrasto, 1.8.1, 1.8.6, 1.14.1). No entanto, a oliveira é inicialmente arbustiva. Interessante é a afirmação relativa a "duas oliveiras nascidas de uma só raiz, uma brava e uma mansa", pois hoje em dia o zambujeiro (oliveira-brava) é utilizado como portaenxerto ou "cavalo" da oliveira. Por isso, os raminhos e folhas da base de uma oliveira (que são do zambujeiro) são diferentes dos da parte superior da árvore. Resta a pergunta: será que a enxertia era praticada na época a que o poema se refere?

${ }^{19}$ Teofrasto refere com frequência estas duas espécies de oliveira, a selvagem e a doméstica (cf. e. g., 1.8.1-2, 1.8.6, 2.3.1).

${ }^{20} \mathrm{O}$ poema insiste na disposição compacta desta vegetação de beira-rio; cf. Od. 6, 127-128.

${ }^{21}$ Cf. Teofrasto 2.5.7: "Em termos gerais, à oliveira, à figueira e à videira é voz corrente que são mais apropriados terrenos planos"; 6.2.4: "Uma particularidade semelhante ocorre com a oliveira, porque dá ideia de que também esta se não dá a mais de trezentos estádios do mar"; cf. 4.2.9.

22 Edwards (1993, p. 47) distingue neste percurso dois espaços, o témenos ainda situado fora da muralha da cidade e os jardins régios já no perímetro urbano. E sobre estes últimos acentua a ordem e fertilidade contínua, que dão aos jardins de Alcínoo um tom de fantástico, ainda que não façam deles um locus amoenus onde tudo nasce espontaneamente. Porque uma intervenção humana parece necessária, ainda que nesses jardins Ulisses não encontre ninguém. Pode então o mesmo estudioso expandir-se numa sugestiva observação: "Esta descrição exemplifica um tópos representado por um certo número de descrições na Odisseia, que incorporam os temas da distância, do clima suave e da
} 
junto à costa, o bosque de Atena vem agora trazer ao herói que pisa terreno desconhecido proteção política, quando está iminente a abordagem da autoridade local. ${ }^{23}$

Mas a verdadeira jóia da flora de cultivo na ilha são os jardins régios, que confinam com o palácio, onde a natureza, os deuses e os homens ${ }^{24}$ parecem colaborar na criação de um lugar de delícias. Em relação à vegetação da ilha de Calipso, sobretudo ornamental dado que a ninfa se alimentava de ambrosia, os jardins de Alcínoo ganham a face humanizada de um espaço que fornece aos homens alimento, ainda que a continuidade da produção não elimine do conjunto o sabor do fantástico ou divino. É que, na medida em que o trabalho humano é apenas discretamente aludido, a versão do jardim dos Feaces distingue-se do que virá a ser a imagem do pomar de Laertes, termo da reintegração de Ulisses na sua casa e identidade, onde a prosperidade que existe sai do esforço do homem. No seu conjunto, no entanto, a descrição da flora nestas sucessivas etapas mantém uma coerência interna, emoldurando a evolução da própria aventura, de um percurso meramente fantástico, por territórios selvagens, para uma paisagem progressivamente mais humana e real. ${ }^{25}$

A atenção de Ulisses cai, antes de mais, num pomar de variedades frutícolas. Alguns pequenos desacertos parecem evidentes na descrição deste lugar especial. Uma primeira qualificação das árvores aí plantadas como "altas" ( $\delta \varepsilon ́ v \delta \rho \varepsilon \alpha \mu \alpha \kappa \rho \alpha ́, ~ O d . ~ 7,114)$ não se ajusta a todas as espécies a seguir enunciadas, "pereiras, romãzeiras e macieiras de frutos brilhantes"

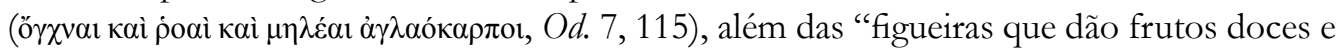

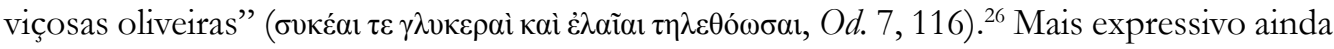
do caráter em certa medida utópico do jardim é o facto de a produção de frutos ser contínua, durante verão e inverno sem interrupção $(O d .7,117-9)$, favorecida por brisas que, enquanto uns se produzem, maturam outros; ${ }^{27}$ a própria expressão poética faz jus a esta caraterística destinada a sublinhar a excecionalidade da ilha $(O d .7,120-1)$ : "A pera amadurece sobre outra pera; a maçã sobre outra maçã; / cacho de uvas sobre outro cacho; figo sobre figo". Mas é

fertilidade, logo de uma vida fácil". Na verdade, no paralelo que os aproxima, os jardins de Alcínoo e o pomar de Laertes são o exemplo do favor dos deuses de que um bom rei é detentor.

${ }^{23}$ É interessante a observação de Haller (2007, p. 149) a este respeito: "Ambos os locais" - isto é, oliveira e bosque de Atena - "são, portanto, essencialmente, espaços humanos de santuário ou refúgio em graus diferentes de proximidade com o espaço político do palácio e cidade de Alcínoo - a oliveira situada nos limites mais remotos do reino de Alcínoo, e o bosque a meio caminho entre a costa isolada e a cidade".

${ }^{24}$ Apesar de mortais, os Feaces têm conexões fortes com a divindade (cf. Od. 5, 35) e os próprios jardins são descritos como "dádivas gloriosas dos deuses" $(O d .7,132)$.

${ }^{25}$ Segal (1962, p. 27) afirma-o com oportunidade: “Os Feaces, por isso, enquanto instrumento do regresso de Ulisses ao mundo da realidade, são também a última etapa do reino de fantasia que ele tem estado a viver".

${ }^{26}$ Há que reconhecer, no entanto, que as árvores de fruto, como, por exemplo, as pereiras podem ser altas, se as não podarem.

${ }^{27}$ Esta mesma noção de produção contínua, que se processa de modo faseado, é referida por Teofrasto, ex., 6.4.8: "Até ao verão, mantém uma floração contínua, com parte das flores em botão, outras já abertas, outras a produzirem semente". 
sobretudo a vinha a merecer a atenção do poeta (Od. 7, 122-6): “Aí está também enraizada a vinha com muitas videiras: / parte dela é em local plano de temperatura amena, / seco pelo Sol; na outra, homens apanham uvas. / Outras uvas são pisadas. À frente estão uvas verdes / que deixam cair a sua flor; outras se tornam escuras". Mesmo assim, os próprios ciclos implicados nesta cadeia ininterrupta de frutificação estão sujeitos a um processo de geração, desenvolvimento e morte que os torna mais próximos da realidade. Por fim, uma vez mais a abundância de água justifica também que, além dos frutos, canteiros de flores prosperem, com extraordinária abundância $(O d .7,127-8) \cdot{ }^{28}$ Em conclusão, a flora da ilha, na sua profusão, emoldura o desenho de uma comunidade feliz, favorecida pela natureza e generosa no acolhimento que dispensa aos seus escassos visitantes. Talvez também para Ulisses, como adiante o retorno ao pomar de Laertes irá mostrar, os jardins de Alcínoo representem algo de familiar, que, apesar da fertilidade maravilhosa que parece bafejá-los, se aproxima mais do regresso de um homem a casa e o distancia, progressivamente, da experiência fraturante da ilha paradisíaca da divina Calipso. Logo a passagem pela terra dos Feaces é um episódio decisivo no efetivo regresso do herói à pátria.

Na sua itinerância tal como a descreve perante os Feaces, Ulisses aportou a outras ilhas, o tipo de território predominante na rota percorrida. Sem justificarem uma descrição tão alongada como a que a de Ogígia e de Esquéria documentam, algumas dessas ilhas são identificadas por um ou outro pormenor de relevância para o nosso ponto de vista, o da vegetação que as cobre. É o caso da terra dos Lotófagos, que Heródoto situa na Líbia (4.177) e Teofrasto (4.3.1-2), confirmando uma localização semelhante, refere como "a ilha dos Lotófagos", talvez correspondente à hoje designada por Djerba e parte do território tunisino. ${ }^{29}$ Neste caso, o próprio nome dos habitantes da ilha, Lotófagos - "comedores de lótus" convida a restringir a menção da flora local à famosa 'flor' que alimentava os habitantes (oi

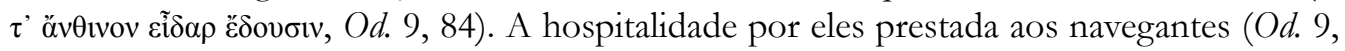

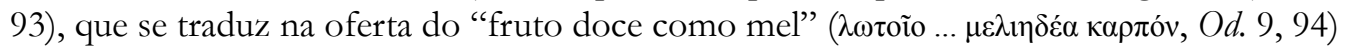
de que se alimentavam, causou inusitado efeito: o do esquecimento daquilo que de facto os devia mover, o propósito do regresso $(\mathrm{Od} .9,95 ; 103)$. Converteu-se, portanto, numa forma amigável de interpor mais uma dificuldade ao nóstos. Teofrasto, que dedica ao lótus uma longa descrição, denuncia com clareza a fantasia tradicionalmente associada a esta comunidade distante e aos poderes da planta de que os Lotófagos se alimentavam; depois de descrever o lótus nas suas caraterísticas fisiológicas, ${ }^{31}$ acrescenta ainda, considerando em particular o

\footnotetext{
${ }^{28}$ Parece claro que a descrição dos ‘jardins de Alcínoo’ corresponde a um tipo de horta utilitária mais do que exótica ou ornamental.

${ }^{29}$ Boardman (2003, p. 28), ainda que com hesitação sobre a geografia da ilha dos Lotófagos, não tem grandes dúvidas de que se trate da costa norte africana, "a única parte da viagem que retira Ulisses das costas da Grécia e talvez da Itália”. Cf. ainda Assunção (2016, p. 276).

${ }^{30}$ Sobre a possível polissemia desta expressão, cf. Assunção (2016, p. 275-6).

31 Teofrasto 4.3.1: “Quanto ao lódão (Celtis australis), toda a árvore em si é peculiar, de bom tamanho, correspondente ao da pereira, ou pouco menos. A folha tem nervuras e é parecida com a do quermes. A madeira é escura. Há várias espécies, que diferem no fruto. Estes são do tamanho de uma fava, e,
} 
fruto: "Quando se come, aquele que se dá entre os chamados Lotófagos é doce, agradável e inofensivo, ou mesmo bom para o estômago; o que não tem caroço (porque há igualmente uma variante com esta caraterística) é mais agradável ainda. Dele se faz também vinho". São, portanto, as virtudes terapêuticas as que lhe merecem atenção, sem deixar de sublinhar que se trata de um produto "inofensivo" quando ingerido, com certeza em resposta implícita ao que o autor de História das plantas sabia ser a tradição. ${ }^{32}$

Seguiu-se, na rota de Ulisses e dos companheiros, a "terra" dos Ciclopes, ${ }^{33}$ repartida entre uma costa marítima e uma pequena ilha fronteiriça, que dela distava o tempo de uma curta navegação ("ora existe uma ilha fértil, que se estende além do porto; da terra dos Ciclopes não fica perto nem longe”, Od. 9, 116-7; cf. Od. 9, 146-50; 166-7; 179-80). ${ }^{34}$ É, portanto, entre estes dois territórios repartidos entre a terra firme e uma ilha, que os famosos monstros de um só olho levam uma existência afastada. Como é convencional na descrição de paisagens utópicas, a primeira informação que a terra dos Ciclopes merece ao narrador é a de uma fertilidade automática (Od. 9, 108-111; cf. Od. 9, 357-8): "nada semeiam com as mãos nem aram a terra, / mas tudo cresce e dá fruto sem se arar ou plantar o solo: / trigo, cevada e as vinhas que dão o vinho a partir / dos grandes cachos que a chuva de Zeus faz crescer." ${ }^{35}$ Se a 'geração espontânea' não é, na Antiguidade, estranha aos teóricos da natureza desde logo como própria das plantas selvagens, a particularidade estará nas espécies conseguidas por este meio, que pertencem ao grupo das que em geral se consideram de cultivo. ${ }^{36}$

no processo de amadurecimento, como acontece com os cachos de uva, mudam de cor. Crescem, tal como os mirtos, apertados uns contra os outros, nos ramos".

${ }^{32}$ Sobre os possíveis efeitos psicotrópicos desta planta, cf. Assunção (2016, p. 282-6).

${ }^{33}$ Tucídides 6.2.1 situa a terra dos Ciclopes na Sicília.

${ }^{34}$ Esta é uma ilha no seu estado bruto, onde não há caça, nem rebanhos, nem terra cultivada; daí a narrativa parte para o território habitado pelos Ciclopes, com condições para possuir um núcleo habitacional estável. Naturalmente que a falta de navegação dos monstros impede o contacto direto entre os dois territórios. Por outro lado, a ilha fronteiriça ao território dos Ciclopes tem todas as caraterísticas de uma paisagem ideal, como Esquéria e Ítaca. Tanto mais flagrante a diferença essencial que a afasta desses territórios: o facto de ser completamente vazia de presença humana.

${ }^{35}$ Não deixa de ser interessante sublinhar que este tipo de produções não se concilia com a ideia de um habitante antropófago como são os Ciclopes. De onde Haller (2007, p. 183) conclui: "Possuem, em bruto, todas as matérias para levar uma vida normal de homens civilizados, mas rejeitam-na, são incapazes de a aceitar, ou não sentem a necessidade de investir no trabalho para viver dessa forma". ${ }^{36}$ Mesmo se a geração espontânea parece um benefício próprio de terras de fantasia, em que a natureza generosamente substitui o homem e o dispensa das penas do trabalho rural, Teofrasto não deixa de registar como o automatismo na produção de plantas pode ocorrer em função de condições climatéricas ou ambientais favoráveis; mais ainda, é uma alternativa natural e corrente ao resultado obtido pelo trabalho do homem (2.1.1): "A reprodução das árvores e das plantas em geral ou é espontânea, ou feita a partir de uma semente, da raiz, por estaca, de um ramo, de um renovo, ou do próprio tronco; ou ainda de madeira partida em pedaços pequenos (é de facto assim que algumas se reproduzem). Destes diversos processos, o principal é a geração espontânea, mas a reprodução a partir de uma semente ou da raiz é tida como a mais natural"; e um pouco adiante (3.1.4), Teofrasto 
Por não disporem de barcos, apesar das condições particulares do território que habitam, os Ciclopes estão impedidos de atravessar para a ilha que lhes fica em frente, o que faz desta um território virgem e uma espécie de laboratório natural. Não deixa de ser curioso registar que o automatismo natural que se verifica no território habitado pelos Ciclopes não tem igual efeito nessa ilha. Apesar de fértil, ela não dispõe de mais do que das habituais florestas que lhe coroam as alturas montanhosas $(O d .9,118)$. Tudo o que implique a intervenção humana - rebanhos e terra cultivada, $O d$. 9, 122-4 - está ausente dessa paisagem bruta. E, no entanto, o potencial do terreno é evidente $(O d .9,132-5)$ : "Há prados junto às margens do mar cinzento, / bem irrigados e amenos, onde as vinhas seriam imperecíveis. / A terra é fácil de arar; e na altura certa poder-se-ia ceifar / excelentes colheitas, de tal forma rico é o solo por baixo". As condições essenciais a uma boa produção existem nesse solo ainda ileso: planícies favoráveis aos prados, água abundante e um solo rico para o cultivo de cereais e vinha, os produtos que podem, basicamente, assegurar a vida humana. ${ }^{37}$

Da distância desta ilha desabitada, os marinheiros puderam ver, no território dos Ciclopes, o quadro convencional de um lugar habitado, ainda que relativamente selvagem porque fora das rotas da civilização $(O d .9,182-5)$ : “ali, perto da costa, vimos uma gruta ao

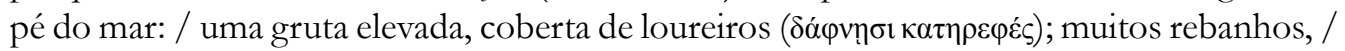
tanto de ovelhas como de cabras, ali dormiam. Em volta / fora construído um alto recinto com pedras metidas na terra / e com grandes pinheiros e carvalhos de copas elevadas

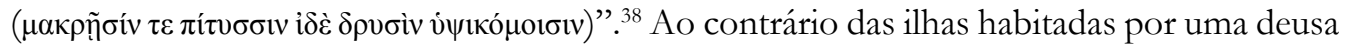
encantadora e por um povo tranquilo e acolhedor, a residência dos Ciclopes não tem prados viçosos nem jardins floridos, como se a natureza acompanhasse, na sua rudeza, a própria brutalidade dos monstros que a habitam.

Em fuga dos Ciclopes, a Ulisses e aos seus homens aguardavam ainda novas provações, oferecendo-se a ilha de Circe $^{39}$ como mais uma escala de perigos imprevistos.

inventaria mesmo um rol de teóricos (Anaxágoras, Diógenes de Apolónia e Clidemo) que defendem a geração espontânea como um ponto de partida para explicar a origem das plantas.

${ }^{37}$ Baumann (1984, p. 34) imagina a Grécia arcaica como sobretudo florestada, consistindo as primeiras marcas da intervenção humana sobre essa paisagem inicial na desflorestação das partes baixas, em resposta às necessidades de habitação e de agricultura de subsistência. Este é, de resto, o ponto de partida para a devastação a que assistimos hoje, em que a área florestada do globo terrestre corresponde a $20 \%$ da floresta que existia quando surgiu a espécie humana.

${ }^{38} \mathrm{O}$ "carvalho de copas elevadas" aparece também associado à flora insular, na ilha do Sol (Od. 12, 357).

${ }^{39}$ Teofrasto (9.15.1) refere-se à ilha de Circe como incluída nos territórios em que, fora da Grécia, abundam plantas medicinais, "as regiões da Tirrénia e o Lácio (onde se diz que vivia Circe) e o Egito". Em 5.8.3, Teofrasto descreve a região habitada pelos Latinos e explica a configuração da chamada ilha de Circe: "A região chamada Circeia é um promontório elevado muito arborizado, com carvalhos, loureiros e mirtos em abundância. Dizem as gentes da região que aí vivia Circe e mostram o túmulo de Elpenor, onde crescem mirtos como os que se usam nas coroas, mas também outros de grande dimensão. Afirma-se que este lugar é um acrescento recente à terra; antes tinha sido a ilha de Circe, mas hoje em dia, graças aos aluviões de alguns rios, ficou ligada ao continente. O tamanho dessa ilha ronda os oitenta estádios”. De acordo com a tradição, Circe vivia na ilha de Eeia, identificada mais 
Solidário perante os riscos que o herói corria, o deus Hermes procura protegê-lo dos filtros da feiticeira com os méritos de uma erva desconhecida, que arrancou do solo e de que the explicou as propriedades (Od. 10, 304-6): "A raiz era negra, mas a flor era como leite. / Os deuses chamam-lhe móli e desenterrá-la é difícil / para homens mortais". Teofrasto, com este passo homérico presente na memória, escreve sobre o móli (9.15.7): "O móli dá-se em Feneu e no monte Cilene. Dizem que esta planta se parece com a referida por Homero; tem uma raiz arredondada, parecida com uma cebola, e uma folha tipo cila. Usa-se para os antídotos e práticas de magia. Mas não é, como diz Homero, difícil de arrancar”. Uma vez mais, a abordagem técnica de Teofrasto despe de fantasia uma tradição, onde, mesmo assim, encontra uma referência de utilidade para a identificação de uma espécie vegetal.

Por fim, cabe a Ítaca, o destino a tão duras penas atingido, uma última reflexão. Ao recordá-la, quando ainda em território feace, Ulisses descreve-a como "soalheira", com uma montanha, "o Nériton, coberto de árvores agitadas pelo vento, bem visível" (Od. 9, 21-2; cf. Od. 13, 351), embora não muito elevado acima do nível do mar (Od. 9, 24-5). ${ }^{41}$ Apesar de muito rochosa ${ }^{42}$ e do seu tamanho não muito extenso, produz cereal e vinho em grande quantidade, além de ser, como em geral as ilhas, abundante em árvores de toda a espécie graças a uma boa irrigação $(O d .13,244-7)$. Os primeiros passos do herói pela sua ilha, de acordo com indicações de Atena - agora, em definitivo, patrocinando-lhe o regresso -, levam-no "por caminhos agrestes, / através de um terreno arborizado por cima das serras" (Od. 14, 1-2; cf. 14, 353), até à primeira habitação que visita, a do porqueiro Eumeu. Com esse primeiro indício de vida humana, apresenta-se também o primeiro sinal de diálogo entre os habitantes e o ecossistema. A assinalar o seu espaço, Eumeu tinha usado "madeira negra de carvalho" para construir uma vedação de estacas $(O d .14,11-2)$.

Este foi apenas o primeiro refúgio dentro da ilha, porque já Ulisses caminha, em companhia de Eumeu, em direção ao palácio. Cumprido o itinerário escarpado de Ítaca, eilos de novo na planície, já próximos do centro urbano. É então que se cruzam com a fonte pública, cercada e sombreada de choupos $(O d .17,208-9)$, que ocultavam uma nascente de água fresca e um altar das ninfas.

tarde pelos Romanos com o promontório de Circeia, no Lácio. Lourenço (2018, p. 317), no entanto, lembra a antiga identificação da ilha de Eeia, onde vivia Circe, a irmã do soberano Eetes e tia de Medeia, com a rota dos Argonautas à Cólquida, ou seja, portanto, ao Oriente, na zona provável do mar Negro. ${ }^{40}$ Este passo da Odisseia constitui a referência mais antiga a esta planta. Por Teofrasto, ela é recordada como mais uma planta dos montes da Arcádia e dela são dados elementos de identificação ausentes de Homero, que eventualmente o autor do tratado poderia ter obtido de outra fonte e associado com os da épica. Sobre esta planta, vide Stannard (1962, p. 254-307), que se propõe distinguir as suas variantes num plano diacrónico, nas múltiplas referências que lhe são feitas ao longo dos séculos. A aludida por Teofrasto é, para este comentador, o Allium nigrum L., não exatamente a referida por Homero. ${ }^{41}$ Lourenço (2018, p. 26) discute longamente as dificuldades que se colocam à identificação da ilha de Ulisses com aquela a que hoje chamamos Ítaca, porque as descrições épicas não se conciliam com a configuração do espaço tal como hoje o podemos observar. Segue a preferência daqueles para quem a ilha do herói deveria ser Cefalénia.

${ }^{42}$ Em Od. 1, 247; Il. 3, 201 chamada de "rochosa" ou "áspera". 
O retomar pleno dos seus direitos sobre Ítaca, cumprida a vingança contra os pretendentes e as servas infiéis, vai exigir de Ulisses que percorra o seu território, dirigindo-

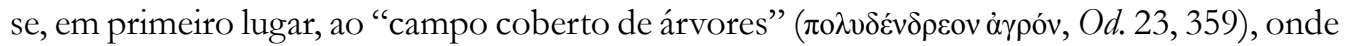
seu pai Laertes curtia as dores da sua ausência. ${ }^{43}$ Em redor da casa habitada pelo velho e pela criadagem que o acompanhava, havia um pomar espaçoso e fecundo, "cheio de frutos"

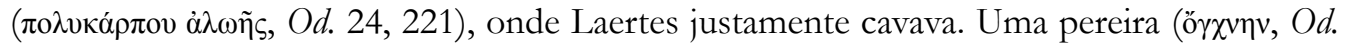
$24,234)$ deu a Ulisses um refúgio momentâneo para avaliar a decrepitude que os anos e o sofrimento tinham marcado sobre o pai, enquanto a tarefa que executava impediu Laertes de olhar de frente o recém-chegado; protelava-se assim o reencontro.

Foi o jardim o tema adotado por Ulisses para abordar Laertes, como se de um desconhecido se tratasse. Louvou-lhe o zelo e o resultado do trabalho, pontuou cada uma das espécies bem cuidadas que povoavam o pomar $(O d .24,244-6)$ :44 "Ancião, não te falta habilidade para tratares do pomar! / Pelo contrário, o teu cuidado é excelente, pois não há / planta, figueira, vinha ou oliveira, pereira ou horta que aqui tenha falta de cuidados". Comparou o viço do espaço com o desmazelo do jardineiro. Mas não resistiu à dor que via estampada em Laertes e em breve o abraçou, tomando como prova de reconhecimento o próprio pomar. De cada uma das espécies, que o pai plantara era Ulisses ainda menino, ${ }^{45} \mathrm{o}$ recém-chegado pôde dar-lhe o número exato $(O d .24,340-2)$ : "Deste-me treze pereiras, dez macieiras / e quarenta figueiras. Prometeste-me também / cinquenta renques de cepas"; ${ }^{6}$ espécies variadas que permitiam manter em permanência a fertilidade do local. Em Ítaca renovava-se a pujança que o então náufrago Ulisses tinha encontrado no reino mítico dos Feaces. Ao mesmo tempo, a narrativa encontrava um fecho pleno neste retornar ao tempo e ao lugar, sendo a própria phýsis parte ativa da reintegração do herói na sua normalidade de vida. Ao tom divino que caraterizava as ilhas de Calipso e de Circe, em Ítaca a prosperidade

\footnotetext{
${ }^{43}$ Esta é, para Henderson (1997, p. 87), "uma retrospetiva significativa e uma re-narração da narrativa". Ou seja, com Ulisses somos levados a retomar passos da sua infância e, com eles, a assistir a um último reconhecimento do herói através do conhecimento das árvores que outrora o pai lhe mostrara. Ao mesmo tempo, não podemos deixar de constatar que, ao contrário da intervenção predadora dos pretendentes no palácio, a vida rural de Ítaca parece de alguma forma ter sido poupada à mesma devastação. Por isso, e no mesmo sentido, tem razão Haller (2006, p. 250) quando afirma que esse lugar é um espaço idílico conquistado pelo trabalho, "que leva o leitor, através dos anos, para um tempo mais simples, anterior à agitação que a guerra de Troia infiltrou na harmonia de Ítaca".

${ }^{44} \mathrm{~A}$ semelhança entre o pomar de Laertes e os jardins de Alcínoo parece evidente, sendo coincidentes as espécies frutícolas que prosperam em ambos.

${ }^{45}$ Henderson (1997, p. 92) vê neste pomar, que Laertes outrora plantou para o filho, diversos elementos simbólicos; em primeiro lugar, um sinal de persistência, de continuidade e de futuro, sendo as árvores e o próprio herdeiro de Ítaca contemporâneos; além disso, um elo entre nóstos e paideía parece também patente neste regresso do herói aos campos da sua infância.

${ }^{46}$ Haller (2007, p. 256) aponta para a coincidência entre as espécies existentes no pomar de Laertes e nos jardins de Alcínoo, mas tendo em conta a finitude do caso de Ítaca. Enquanto, em Esquéria, os frutos se sucedem sem cessar, no caso de Ítaca cada uma das espécies obedece a um número determinado e finito.
} 
parecia ter uma origem sobretudo 'política'; fecundidade da terra e boa governança apresentam-se como duas condições concomitantes de eudaimonía (cf. Od. 19, 109-14). ${ }^{47} \mathrm{Com}$ o seu ininterrupto reverdecimento, a terra exprimia, por isso, uma espécie de resistência acompanhando a do navegante, a da esposa assediada e a do velho rei de Ítaca exilado da cidade -, de modo a contribuir para a reintegração do senhor da casa e da família real na rota de uma legítima prosperidade.

\section{O CONTINENTE}

A reunião de guerreiros gregos em Troia, provenientes de todo o continente helénico, é um argumento para justificar referências a múltiplas paisagens e regiões, ainda que a menção a territórios férteis se limite a alguns casos específicos e de potencial diversificado. A distribuição adequada das caraterísticas de cada paisagem não deixa dúvidas sobre o conhecimento direto que o poeta da Ilíada delas tinha. Se começarmos pela pátria de origem do melhor dos heróis aqueus combatentes em Troia, Aquiles, é na Grécia do norte que se

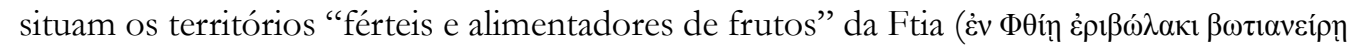
/ карлóv, Il. 1, 155-6; cf. Il. 9, 363; 9, 479), onde os gados abundam, bem como as vertentes bem arborizadas do Pélion (Il. 2, 757). Mas quando se trata de fazer o catálogo das forças reunidas nos campos de Ílion, a menção convencional às suas pátrias de origem multiplicase. É o caso do célebre 'catálogo das naus' do Canto II da Ilíada. A fertilidade variada da

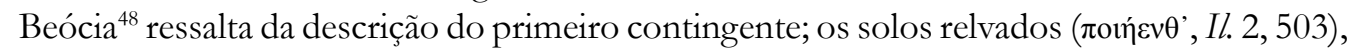
os bosques reluzentes de Posídon (Il. 2, 506) e a abundância dos vinhedos ( $\pi \circ \lambda v \sigma \tau \alpha \dot{\varphi} \varphi v \lambda o v$, Il. 2, 507) (9) $^{9}$ assinalam-lhe o viço. Também a Tessália impressiona pelo seu solo arável (Il. 2,

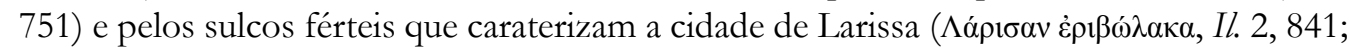

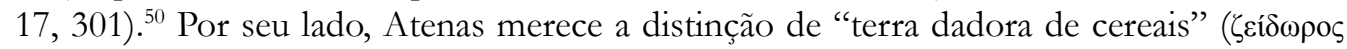
öрovpa, Il. 2, 548).

Além dos catálogos, outros momentos há no poema em que um guerreiro recorda a sua ascendência e, com ela, um trajeto de vida e a paisagem que associa com a sua família. É o caso de Diomedes que, ao retomar a sua genealogia, recorda a ida do pai, Tideu, para Argos, onde casou e se estabeleceu; e a propósito, recupera a imagem fértil da região (Il. 14, 121-4): “[...] e morou em casa / de sustento abundante e suficientes eram as suas searas /

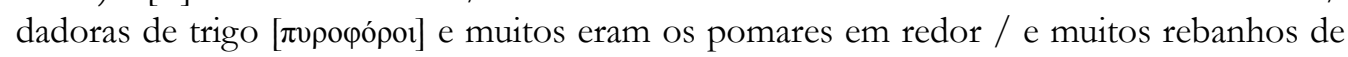
ovelhas possuía". ${ }^{51}$

\footnotetext{
${ }^{47}$ Muito a propósito sintetiza Haller (2007, p. 102): “A conexão, na literatura grega arcaica, entre reis, veredictos justos e prosperidade cívica e agrícola é em geral reconhecida".

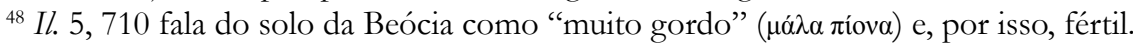

${ }^{49}$ Este mesmo epíteto é atribuído à ilha de Eubeia (Il. 2, 537). Vinhedos não faltam também em Epidauro, ’’ $\mu \pi \varepsilon \lambda$ ó$_{\varepsilon v \tau^{\prime}}($ Il. 2, 561).

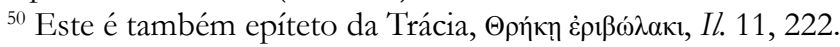

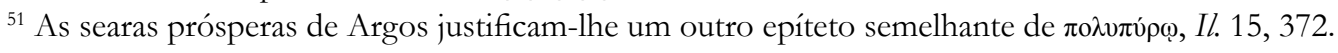


Por outro lado, se as ilhas são, no roteiro de Ulisses, a configuração geográfica mais habitual, nem por isso a Odisseia deixa de referir paisagens continentais associadas com a pátria de origem dos heróis ou com a itinerância de Ulisses. Talvez uma distinção básica entre a maior fertilidade da terra firme diante da aridez tendencial das ilhas se possa retirar da dúvida de Ulisses, que ao longe avista Ítaca, sem saber ainda ao certo de que território se trata $(O d .13,234-5)$ : "É uma ilha soalheira, ou a praia de um continente / de terra fértil

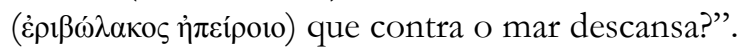

Esta impressão geral parece confirmada na Telemaquia, em associação com a configuração do terreno. Em território grego, Esparta é uma das regiões que desperta a atenção do poeta da Odisseia pela amplitude ${ }^{52}$ e fertilidade dos seus campos. Perante Menelau, Telémaco elogia-lhe a qualidade, tanto mais impressionante se considerada por contraste com a aridez da sua ilha natal $(\mathrm{Od} .4,602-8)$ : “Tu és rei de uma vasta planície / onde há abundância de trevo-morango, ${ }^{53}$ junça, ${ }^{54}$ trigo e escanha $; 5$ / e da branca cevada de espiga larga. / Em Ítaca não há amplas estradas nem pradaria: / é terra apascentadora de cabras, mais bela que as terras / apascentadoras de cavalos. / Nenhuma das ilhas é apta para cavalos nem é de boa pradaria. / Descem para o mar a pique; e Ítaca mais do que as outras".

Fora da Grécia, o Egito é referido nos Poemas Homéricos como um território de invejável prosperidade - "terra dadora de cereais", Od. 4, 229; "os belos campos dos Egípcios”, Od. 14, 263 - e produtor de espécies específicas, ${ }^{56}$ particularmente associados

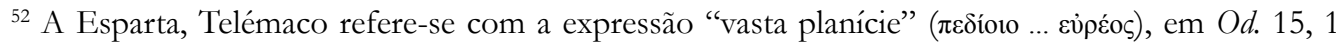

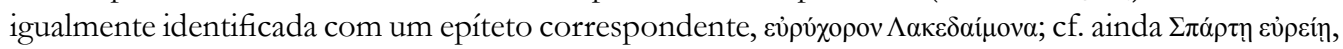
Od. 11, 460; 12 .

${ }^{53} \Lambda \omega \tau$ có é uma designação que, em Teofrasto, identifica diferentes plantas. Em História das plantas 7.8.3, 7.13.5, o $\lambda \omega \tau$ có é referido como uma leguminosa, eventualmente Trifolium fragiferum L. Em 9.7.3, o mesmo nome é dado a uma planta aromática, usada no fabrico de perfumes, o meliloto (Trigonella foenum-graecum L. ou Melilotus officinalis (L.) Pall.). É mais provável que Homero se esteja a referir à primeira destas duas espécies.

${ }^{54}$ Em História das plantas 1.10.5, 4.8.1, 4.10.1, 4.10.5-6, a junça é referida entre espécies próprias dos pântanos, e bem conhecida na Grécia e no Egito.

${ }^{55}$ A escanha é referida, em História das plantas 4.4.10, como uma alternativa grega ao arroz indiano. Em 8.9.1-2, Teofrasto identifica-a entre os cereais elementares, assemelha-a ao trigo e à cevada e refere-lhe as exigências: precisa de um solo gorduroso e rico, e é das plantas que mais desgasta o terreno em que está implantada.

${ }^{56}$ A noção, transmitida por História das plantas, de que algumas regiões são privilegiadas e permitem uma qualidade ou mesmo reabilitação de algumas espécies dá ao Egito, entre outras, um estatuto de excepção: ex., 1.9.5: "Mais abaixo, no Delta, é muito curto o período de tempo em que as plantas não rebentam"; 2.2.7, “Tal alteração, ao que se ouve dizer, ocorre apenas com a romãzeira, no Egito e na Cilícia; no Egito, uma árvore de fruto ácido, nascida de semente ou de rebentos, produz um outro doce ou com sabor a vinho". O Egito parece, assim, um dos territórios privilegiados pela especificidade e raridade das suas espécies, ou por comportamentos particulares que as condições de clima e solo favorecem. Muitas são as referências que lhe vão sendo dedicadas, como um território de caraterísticas peculiares e de grande exuberância no que respeita à produção vegetal. Exemplifiquemos 
com o país dos faraós, conhecido pela competência médica, são os fármacos, uns venenosos, outros benéficos (Od. 4, 229-32b).

E naturalmente, tendo sido Troia o alvo que desencadeou a aventura aqueia e o território em que a guerra se alongou por dez anos, não se estranhará que a descrição da sua paisagem esteja subjacente à narrativa dos acontecimentos militares. Em termos gerais, a região de Ílion, por ser cruzada de vários rios, tem caraterísticas próprias de uma região irrigada. O poeta da Ilíada recorda as pradarias que se alongam "junto às correntes do Caístro" (Il. 2, 461-465), sobrevoadas por numerosos bandos de aves, do mesmo modo que os guerreiros gregos "se posicionaram então na pradaria florida do Escamandro / aos milhares, como as folhas e as flores na época própria”. Desta paisagem fazem parte os juncos e pântanos que serviram de esconderijo aos invasores (Od. 14, 474). Por seu lado, "o trevo-

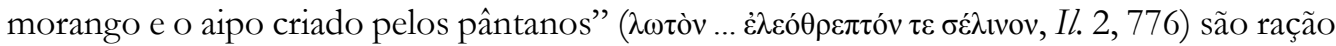
privilegiada para os cavalos em que Troia abunda. Pontualmente uma espécie determinada pode servir de cenário para um episódio; é o caso da tamargueira, também ela uma árvore de ambientes húmidos, ou mesmo uma anfíbia (HP 1.4.3), onde Ulisses e Diomedes escondem os despojos de Dólon que acabam de assassinar; depois entrelaçam-lhe os ramos, de modo a reconhecerem-na, no regresso da incursão no acampamento inimigo (Il. 10, 465-7). Aos terrenos de Príamo, o poeta da Ilíada aplica o mesmo epíteto que lhe mereceram outros territórios produtivos, como as planícies da Tessália, por exemplo, "de férteis sulcos" (Tpoínv

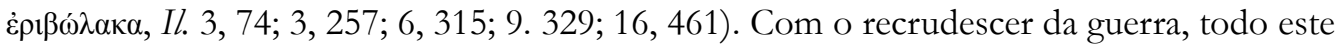
território produtivo se converteu em terreno de perigos e ciladas. Assim Lícaon, um dos príncipes de Troia, foi capturado por Aquiles quando, no pomar paterno, colhia rebentos de uma oliveira para equipar o seu carro (Il. 21, 34-9).

Pontualmente, um elemento vegetal pode ser referência de um lugar determinado

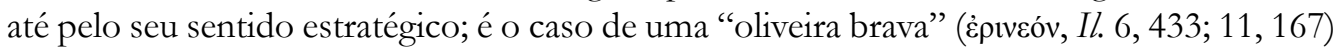
que marca um ponto de maior vulnerabilidade na penetração das muralhas da cidadela; ou de um carvalho ( $\varphi$ үóv, Il. 9, 354; 11, 170) que assinala os limites a que os Troianos se atreviam quando Aquiles se mantinha ativo no exército.

com alguns casos: o sicómoro egípcio apresenta uma caraterística que se percebe rara, a de ter os frutos no tronco $(1.1 .7,1.14 .2)$. A própria designação desta espécie concreta - sicómoro egípcio - a vincula com uma determinada região. Por outro lado, a especificidade regional pode até traduzir-se por um termo próprio, que não se satisfaz com um adjetivo remissivo para a região, mas com um termo local, que o grego sente como estranho: em 1.1.7, é referida uma espécie egípcia como "aquela a que, no Egipto, chamam vingon", de que 1.6.11 elogia o valor alimentar e as condições locais que justificam a diferença: "Tem uma excelente qualidade e é comestível; apanham-na quando o rio desce, revolvendo a terra". A excecionalidade da reação de certas espécies no Egito merece reparo, podendo mesmo identificar-se locais particulares no mapa desta região que assinalam afinidades; assim (1.9.5), "Há as $<$ folhas $>$ que, não sendo persistentes por natureza, passam a sê-lo em função do habitat, como se disse a propósito das de Elefantina e de Mênfis". No séc. IV a.C., o conhecimento do Egito tinha-se aprofundado e permitido este tipo de avaliação circunstanciada. 
Das diferentes regiões da Anatólia de onde provêm os aliados de Troia predomina a ideia de uma paisagem produtiva. A Frígia, por exemplo, é "cheia de vinhas" (’̊ $\mu \pi \varepsilon \lambda o ́ \varepsilon \sigma \sigma \alpha v$,

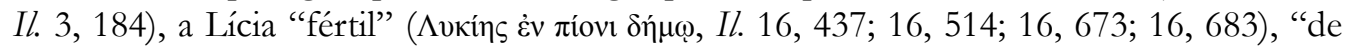

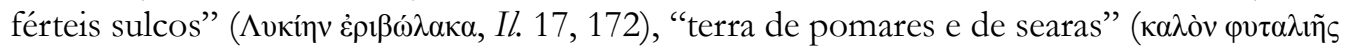

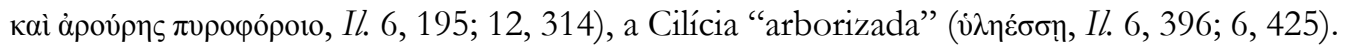

Mas além das planícies agrícolas e das pradarias, as escarpas do Ida eram também emblemáticas do reino de Príamo. Cruzado por muitas fontes, as suas encostas cerradas e povoadas de feras exibiam uma floresta densa e alta (Il. 14, 283-4), de que algumas espécies se destacavam, como "um pinheiro altíssimo", "que chegava por entre o nevoeiro até ao céu" (Il. 14, 287-8), ou os carvalhos de copas elevadas (Il. 23, 118). O Ida apresenta, portanto, o aspeto genuíno de uma zona florestada, escassamente habitada, onde a natureza continua a reinar no seu estado puro. A perseguição que Aquiles desencadeia contra Heitor permite o avanço através do Ida e traz memórias do tempo em que a paz reinava nos seus recessos (Il. 22, 145-56). Uma oliveira (vide supra Il. 6, 433; 11, 167), sacudida pelo vento, estabelece o limite que dá acesso às primeiras nascentes, as do Escamandro. A mesma paz era então a moldura que enquadrava cenas bucólicas, em que pastores, mais tarde transformados em guerreiros, apascentavam os seus rebanhos. Além disso, as florestas do Ida continuaram a servir de esconderijo a guerreiros troianos em fuga, que aí encontravam refúgio, até que a noite lhes permitisse o retorno seguro à cidadela (Il. 21, 556-61).

Quando a guerra veio perturbar a tranquilidade das tarefas domésticas, o Ida continuou ainda a oferecer a riqueza das suas madeiras, agora quase inacessíveis aos Troianos, porque cercados dentro das muralhas e receosos dessa exposição ao inimigo. Em contrapartida, é sobretudo ao inimigo que o Ida passou a abastecer dos materiais em que era fértil. Foi com tábuas de pinheiro do Ida e colmo dos prados que os Mirmidões construíram a tenda de campanha de Aquiles (Il. 24, 450-1). E, na hora de homenagear o cadáver de Pátroclo, foi também aos carvalhos do Ida que os Aqueus foram buscar o combustível necessário (Il. 23, 117-21).

\section{TERritórios SAgRAdos OU FANTÁSticos}

Tomemos por emblemático aquele território divino onde Zeus e Hera vivem um encontro amoroso (Il. 14, 347-9): "Debaixo deles a terra divina fez crescer relva fresca / a flor de lótus orvalhada e açafrão e jacintos macios / em profusão, que os mantiveram acima do solo". Esta é a imagem de uma "terra divina" por excelência $(\chi \theta \dot{\omega} v \delta \tilde{\imath} \alpha)$, onde predominam o viço, a cor e macieza de relvados e flores.

Por seu lado, a veneração dos deuses nos múltiplos recintos sagrados que povoavam o mundo antigo ${ }^{57}$ - de que fazem parte bosques, pastagens e jardins - está muitas vezes

\footnotetext{
${ }^{57}$ Naturalmente estes são lugares alternativos para o culto, fora das cidades. Edwards (1973, p. 38) chama a atenção para o facto de não haver, nos Poemas Homéricos, referência a templos fora do círculo urbano, mas sim a recintos sagrados ou grutas. Mais tarde, quando o templo passou a centrar o culto, o contorno sagrado que o rodeava manteve uma simbologia vegetal associada com cada culto
} 
associada com a presença emblemática de uma espécie vegetal que simbolize o senhor do témenos. Os Poemas Homéricos contêm já uma espécie de roteiro de lugares e espécies, normalmente identificadas por árvores, como os exemplares mais 'perfeitos' da criação vegetal. $^{58}$

Em território grego, continental ou insular, as divindades supremas do Olimpo e os seus templos têm por logótipo espécies determinadas. Assim o pai dos deuses, no seu célebre santuário de Dodona, ${ }^{59}$ dispõe de um carvalho, a mais robusta das árvores, como de um canal transmissor da sua vontade e dos seus desígnios (Il. 16, 220-5; Od. 14, 327-8; 19, 296-7): "Quanto a Odisseu, disse que a Dodona se dirigira, para lá / ouvir do alto carvalho do deus a vontade de Zeus". Por seu lado de Apolo, e da ilha que o viu nascer, é bem conhecida "a palmeira de Delos" - protetora de Leto ao dar à luz o próprio deus - e a pujança com "que se erguia no ar" (Od. 6, 162-3). ${ }^{60}$ De Ísmaro, na Trácia, Ulisses recordava o acolhimento que lhe havia sido dado pelo sacerdote de Apolo, o deus tutelar da região (cf. Il. 1, 37-8), venerado

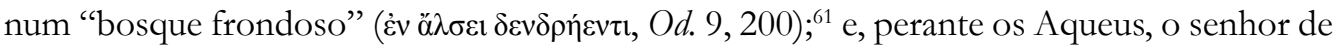

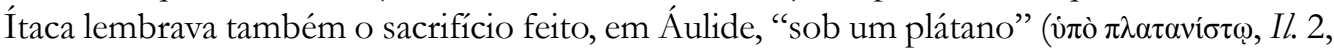
307), num recinto onde uma fonte de água transparente e altares assinalavam a presença do

em particular, mesclando espécies selvagens e de cultivo, dada - como afirma Miles (2016, p. 170) - a própria índole compósita da divindade.

${ }^{58}$ Por Teofrasto, as árvores são consideradas paradigmáticas na classificação que pretende esboçar (1.1.11). Tomadas como modelo, é a partir delas que, demarcando diferenças (abundância ou carência, densidade ou rarefação, por exemplo), pretende caraterizar melhor as restantes plantas; no reino vegetal, parece caber assim às árvores o papel que, entre os animais, cabe ao Homem, como o mais bem conhecido e mais perfeito de todos os seres dessa espécie. Esta é uma metodologia que obedece a um enunciado prático (1.2.3): "Mas como se deve avançar do que é conhecido para chegar ao desconhecido, e mais conhecido é o que é maior e mais patente aos nossos sentidos, é óbvio que se deve tratar destes assuntos de acordo com essa metodologia”. Uma lógica de paralelismo permitirá, a partir do que é conhecido e percetível, especular sobre o desconhecido e menos acessível.

${ }^{59}$ Há, na Ilíada, duas referências à "invernosa Dodona": Il. 2, 750; 16, 233-4. Por outro lado, a associação de Zeus com diversas espécies de carvalho, como sua árvore sagrada, repete-se; cf. Il. 5,

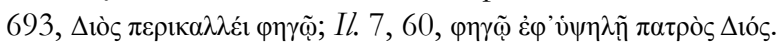

${ }^{60}$ Nos Poemas Homéricos esta é a única menção à ilha e à palmeira de Delos, como de resto à espécie 'palmeira' em geral ( $\varphi$ oĩvı). . Teofrasto, por seu lado, refere-se à palmeira de Delos ao pretender exemplificar 'espécies de longa duração’ e os exemplos de que se serve são todos referidos a recintos sacros (4.13.2): "A longevidade de algumas plantas, quer cultivadas quer selvagens, é também testemunhada por versões transmitidas pelo mito; assim acontece, ao que dizem, com a oliveira em Atenas, com a palmeira em Delos e, em Olímpia, com a oliveira selvagem de que se faz as coroas; ou ainda com os carvalho-avelanedos em Ílion, plantados no memorial de Ilo. Há quem diga também que foi Agamémnon quem plantou o plátano em Delfos, e também o de Cáfias, na Arcádia”. Cícero (Leis 1.1.2) e Plínio (História natural 16.240) testemunham ainda tê-lo visto. Sobre as diversas tradições relacionadas com esta árvore, cf. Miles (2016, p. 170-1).

${ }^{61}$ 'A $\lambda \sigma o \varsigma$ é, de resto, um vocábulo comprometido com a referência aos bosques sagrados; cf., no caso de Atena, $O d$. 6, 321-2. Mesmo no Hades, Perséfone detém um recinto equivalente $(O d .10,509)$. 
divino; ${ }^{62}$ de resto, a árvore serviu de cenário a um prodígio, quando uma serpente tremenda devorou as oito crias e a mãe-ave que se ocultavam na sua folhagem, numa promessa evidente da futura conquista de Troia ao fim de outros tantos anos. Deusas menores, como as Ninfas, vêm multiplicados os recintos onde são veneradas; a descrição de Ítaca (Od. 13, 102-4; cf. $O d .13,122 ; 13,345-50 ; 13,372)$ inclui a menção de um desses lugares: "No cabeço deste porto está uma oliveira de esguias folhas, / e perto dela há uma gruta aprazível e sombria, / consagrada às Ninfas que têm por nome Náiades”. O enquadramento é, sem dúvida, convencional: a preferência por um lugar elevado, a frescura sombria de uma gruta e a oliveira como árvore destacada são tópicos marcantes na identidade sacra do lugar. Se as árvores parecem dominar nos recintos sacros, casos há em que o qualificativo usado é o

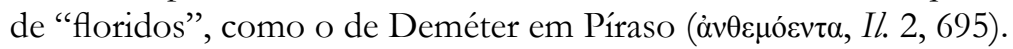

A distância proporciona um aprofundamento de fantasia na relação entre entidades obscuras e espécies florestais. Do Egito, o poeta da Odisseia $(4,458)$ recorda a "árvore de

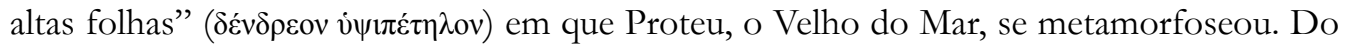
estreito onde Caríbdis ameaçava os navegantes, o mesmo poema refere "uma figueira alta", de raízes poderosas e ramos inalcançáveis de tão elevados (Od. 12, 432-6). Em contrapartida, talvez a sedução própria das Sereias justifique que, na paisagem com elas associada, a maior brutalidade das espécies florestais seja substituída pela doçura dos prados floridos (Od. $12,45 ; 12,159)$. Por fim, na própria geografia do Hades, as caraterísticas da natureza são projetadas com ligeiros acertos. Como viajante de tão inacessíveis paragens, Ulisses (Od. 11, 510-5) pôde observar que, nas imediações dos rios infernais, se acumulavam espécies

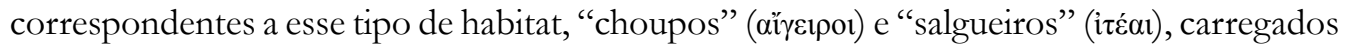

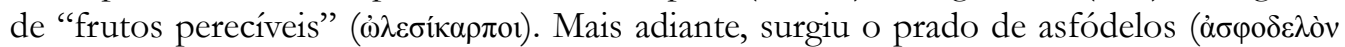
$\lambda \varepsilon \mu \tilde{\omega} v \alpha, O d .11,539 ; 11,573)$, com o seu tom pálido e sombrio. E se viço existia nas paragens infernais, à imagem da fertilidade dos jardins de Alcínoo ou dos pomares de Laertes, estava associado não com benesses, mas com punições; é assim o arvoredo carregado de frutos, mas inacessível, que rodeia um Tântalo faminto (Od. 11, 588-92): "Havia árvores altas e frondosas que deixavam pender os seus frutos, / pereiras, romãzeiras e macieiras de frutos brilhantes; / figueiras que dão figos doces e viçosas oliveiras. / Mas quando o ancião estendia as mãos para os frutos, / arrebatava-os o vento para as nuvens sombrias".

\section{A Flora AO SERVIÇO DA POESIA: OS SÍMILES}

São bem conhecidas as imagens poéticas da convenção épica, nomeadamente os símiles, e o largo espetro de campos semânticos nelas envolvidos. Não é, portanto, de estranhar que a flora - como a natureza em geral - possa dar também neste aspeto o seu contributo. Além da variedade das espécies, este tipo de imagens poéticas desenvolve elementos de pormenor num conhecimento minucioso e direto dos exemplares envolvidos.

${ }^{62}$ Mais uma vez Pausânias (9.19.7-8) testemunha a existência desta árvore em Áulide. 
O passar das estações e os fatores climatéricos que acarreta são inspiradores de vários significados. A doçura da primavera, fértil em folhas e flores sugestivas de abundância, serve de paralelo feliz para descrever uma multidão (Od. 9, 51-2; cf. Il. 2, 87-9). Por outro lado, do mesmo modo que os ventos tempestuosos do outono se conciliam para amontoar, numa massa, plantas espinhosas que rolam no solo, assim também ventos adversos se desencadearam contra o Ulisses navegante $(O d .5,328-30)$. Os movimentos da multidão dos Aqueus, quando, depois de ouvir as palavras da chefia, se desloca no acampamento, lembra o efeito do vento sobre as searas, que ondulam suavemente (Il. 2, 147-9).

Além de metáfora para exprimir os movimentos das massas ou dos elementos atmosféricos, o mundo vegetal proporciona também uma imagética útil ao desenho da beleza humana. Para tudo o que é suave ou delicado na criatura humana são as flores o paralelo escolhido. Assim, depois de lavada, a cabeleira de Ulisses assemelha-se à flor do jacinto

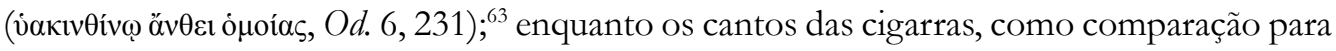

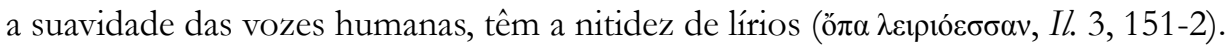

A agitação do combate pode também encontrar na metáfora vegetal uma forma adequada de se tornar palpável. ${ }^{64} \mathrm{~A}$ nuvem de pó que envolve os exércitos em movimento, por exemplo, produz uma comparação com o efeito do joio nas searas (Il. 5, 499-502): “Tal como o vento dispersa o joio nas eiras sagradas [...], / na altura em que a loira Deméter / separa o trigo do joio entre rajadas de vento / e os montes de joio se embranquecem [...]". Com a mesma realidade na memória, Teofrasto descreve a degenerescência de trigo em joio e uma espécie de penugem que este processo dispersa pelos campos (8.7.1). ${ }^{65}$ Outra imagem

${ }^{63}$ Irwin (1990, p. 205) sintetiza as interpretações desta expressão, ora como alusivas à disposição 'enrolada' das folhas do jacinto, ora como à sua tonalidade escura. Mas adiante (Irwin, 1990, p. 208-9) a mesma comentadora valoriza a ideia de que a comparação com flores se pode referir a diferentes qualidades, de textura, fragrância, som ou colorido. Este mesmo qualificativo aplica-se, por exemplo, à textura fina da pele $($ Il. 13, 830). Entendê-lo, no caso da cabeleira de Ulisses, como alusivo a uma cor escura entra em contradição com a referência à cabeleira loira do herói, mencionada em $\mathrm{Od}$. 13, 431. Logo talvez outro sentido deva ser preferido, como a ideia de "encaracolado" defendida por outros testemunhos (cf. Od. 16, 175; Eustátio 251). Irwin (1990, p. 214-5) lembra ainda que é mais ou menos consensual que o jacinto da época clássica não é o Hyacinthus orientalis L., uma planta oriental que provavelmente chegou à Grécia e se propagou numa variante selvagem já após a época clássica. Talvez seja preferível identificar o jacinto referido por Homero com a Scilla bifolia L., "uma flor que seria também compatível com a outra única ocorrência do jacinto em Homero, onde cresce juntamente com o açafrão e o trevo-morango ( $\lambda \omega \tau$ tós) na cena da sedução de Zeus por Hera $(I l .14,348)$ ".

${ }^{64}$ Moulton (1974, p. 382-3) estabelece proporções interessantes entre os tipos de símile e a sua ocorrência nos dois poemas. Assim conclui que 3/4 dos símiles da Ilíada ocorrem em cenas de batalha. Por outro lado, sublinha também que os símiles da Odisseia correspondem a $1 / 3$ dos da Ilíada, o que talvez se justifique, segundo a sua opinião, "pela necessidade reduzida de tirar relevo da narrativa, dada a variedade crescente de geografias, incidentes e temas".

65 "Enquanto que, das outras sementes, nenhuma degenera e se transforma noutra, dizem que o trigo e a cevada se transformam em joio, sobretudo o trigo. Isso acontece mais em zonas chuvosas e principalmente em terrenos muito húmidos e fustigados pela chuva. É que o joio não é uma planta 
expressiva para o vigor do recontro entre os dois exércitos é a do efeito dos ventos sobre a ramaria da floresta (Il. 16, 765-70): “Tal como o Euro e o Noto lutam à compita entre si / quando fazem estremecer o fundo bosque de um vale / na montanha, bosque de carvalhos e freixos e de lisos cornisos ( embater entre si as longas ramagens / com assombroso fragor e surge o estrepitar de ramos partidos - / assim Troianos e Aqueus se atiraram uns contra os outros [...]".

Tal como as árvores podem aparecer como exemplo de firmeza ou serem abatidas, o mesmo sucede com os heróis no campo de luta. A resistência no combate pode então encontrar nas espécies de grande porte, que resistem às intempéries, uma imagem adequada (Il. 12, 131-6): "Estes dois estavam à frente dos elevados portões, / como dois carvalhos de alta copa nas montanhas, / que todos os dias aguentam o vento e a chuva, / bem firmes devido à grande extensão das raízes - / assim estes dois, confiantes na força dos braços, / aguentaram a arremetida do grande Ásio sem arredar pé". Mas mesmo os carvalhos, imagem da árvore resistente por excelência, podem ceder à força de Zeus e, expostos pela sua própria altura à violência dos elementos, ruir de forma assustadora, do mesmo modo que cedem os melhores dos guerreiros ao vendaval do combate (Il. 14, 414-8): “Tal como quando pelo raio de Zeus pai um carvalho / é arrancado pelas raízes e dele surge um cheiro terrível / a enxofre; [...] assim tombou no chão depressa a Força de Heitor na poeira". Uma bela oliveira, tão caraterística da paisagem mediterrânica, pode servir o mesmo tipo de imagem (Il. 17, 5360): "Tal como o lavrador trata de uma pujante vergôntea de oliveira / em terreno solitário, onde brota quantidade suficiente de água: / árvore bela e frondosa, à qual fazem estremecer as brisas / de todos os ventos e floresce com flores de cor branca; / mas de repente vem a rajada de uma desmedida tempestade / e arranca a árvore da terra, deixando-a estatelada no chão - / assim a Euforbo [...] / o Atrida Menelau matou”.

No cenário de guerra, onde a morte é frequente, as árvores de grande porte servem de imagem para a queda, digna, do guerreiro. Simoésio, uma vítima do poderoso Ájax,

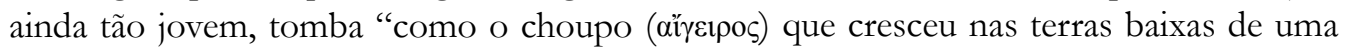
grande pradaria, / liso, mas com ramos viçosos na parte de cima - / álamo que com o ferro fulgente o homem fazedor de carros / cortou para com ele fabricar um lindíssimo carro, / e que deixou a secar, jazente, na ribeira de um rio" (Il. 4, 482-7). Sobre o choupo, sempre corretamente colocado em terrenos húmidos, o poeta acrescenta agora mais alguns traços: "liso" corresponde talvez ao que Teofrasto virá a exprimir, sobre o caule da mesma espécie, como "de casca carnuda" (HP 1.5.3); de "ramos viçosos", correspondendo a uma caraterística também referida em HP 3.13.3, que toma o choupo como exemplo de uma

de primavera, como a outra erva - apesar do que alguns tentam fazer crer -, e a prova está em que é logo que o inverno começa que ele aparece e se desenvolve [...]. A penugem existe também nas folhas do trigo-de-perdiz, mas neste caso só se torna visível na primavera. Esta é uma particularidade deste tipo de plantas, e ainda do linho, que também, ao que se diz, se transforma em joio.” Esta opinião corrente em relação ao linho não tem fundamento científico. 
árvore de muitos ramos ${ }^{66} \mathrm{e}$ de alta copa (cf. HP 4.7.4). A noção de que a madeira do choupo é húmida - necessitando, portanto, de secar para ser utilizável - é igualmente abonada por

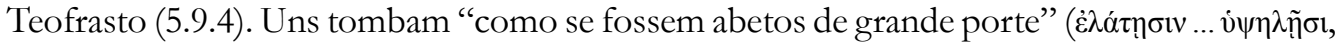
Il. 5, 560); outros cedem "como o freixo ( $\mu \varepsilon \lambda i$ in) / que no cume da montanha, visível ao longe de todos os lados, / é cortado pelo bronze e ao chão faz tombar a tenra folhagem" (Il. 13, 178-80); ${ }^{67}$ outros ainda "como tomba carvalho ou choupo / ou alto pinheiro, que nas montanhas os carpinteiros / cortam com machados afiados para a construção das naus [...]" (Il. 13, 389-91; 16, 482-4). ${ }^{68}$

Menos vistosa é a morte daqueles que se apagam sem resistência, feridos por um golpe imprevisto do inimigo; foi o que aconteceu com um dos filhos de Príamo alvejado por

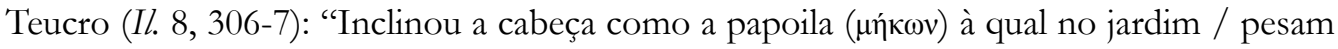
as sementes e as chuvas da primavera - assim inclinou a cabeça, pesada devido ao elmo". Fragilidade e total falta de reação justificam este outro símile de morte.

No entanto, mais do que todos famoso como expressivo da mortalidade inerente à espécie humana, não a que distingue heróis no campo de batalha, mas a que penaliza por igual todos os mortais, é o símile das folhas (Il. 6, 146-9), expressivo de um ciclo de renovação natural que as árvores experimentam, mas que está vedado à espécie humana.

\footnotetext{
${ }^{66}$ Eis a descrição que Teofrasto dá do choupo (3.14.2): “O álamo e o choupo só têm uma espécie; ambos são eretos, sendo o choupo muito mais alto, mais solto e mais liso".

${ }^{67}$ Também Teofrasto cita o freixo entre as árvores de montanha (3.3.1) e dedica à sua folhagem uma longa descrição (3.11.3): "Há também duas espécies de freixo: uma é alta e robusta, com uma madeira branca, de boa fibra, bastante leve, sem nós e mais compacta; a outra mais baixa, menos vigorosa, com uma madeira áspera, mais dura e mais amarelada. As folhas, no formato, são parecidas com as do loureiro, isto é, do loureiro de folha larga, mas mais estreitas na ponta, de rebordo dentado e com picos. Na sua totalidade a folhagem (talvez se lhe possa chamar folhagem, porque cai de uma só vez) parte de um só pedúnculo. É também, por assim dizer, a partir de uma só nervura, que as folhas nascem aos pares numa mesma articulação, de um e de outro lado, em grande número e destacadas, de mesmo modo que na sorbeira. Em algumas folhas os espaços entre os nós são curtos e os pares em menor quantidade, mas nas da espécie branca os espaços são maiores e os pares mais numerosos; aí as folhas são também mais compridas e mais estreitas, com uma cor verde como a do alho".

${ }^{68}$ A aproximação entre as diversas madeiras e a sua utilidade, nomeadamente na construção naval, é também uma preocupação de Teofrasto. A construção naval correspondeu a uma atividade de grande importância num país de costa como a Grécia, no transporte de pessoas e mercadorias, na pesca e também na guerra. Não admira portanto que Teofrasto lhe dedicasse uma longa reflexão (5.7.1-3), de que faz parte, em primeiro lugar, a menção das espécies mais apropriadas - o abeto, o pinheiro e o cedro -, e depois a sua utilização específica, consoante o tipo de embarcação de que se trata (cf. 5.4.3, 5.7.1). Importa também, além da estrutura geral, reconhecer a preferência de certas espécies para componentes determinadas da embarcação, caso do carvalho quando se trata da quilha, "para resistir ao reboque para terra", ou das peças feitas ao torno, "que requerem uma madeira maleável e robusta". Porque as propriedades de cada componente têm de ser tidas em consideração: robustez, flexibilidade, peso ou leveza, resistência ao apodrecimento.
} 
Logo a versatilidade da natureza vegetal, quer se trate do vigor das árvores, quer da delicadeza das flores, constitui uma interessante fonte de inspiração poética, tratada pelo poeta com particular minúcia e precisão.

\section{ConClusão}

A descrição de paisagens, quer se trate de contextos de pura ficção poética, quer de referências a quadros verosímeis, tem na Odisseia uma muito maior expansão. Podemos mesmo considerar, dado o paralelo entre as sucessivas descrições e a evolução do itinerário do herói, que a forma de delinear diversos pontos de escala - ilha de Calipso, terra dos Feaces, Ítaca - constitui uma linha de ação determinante em todo o nóstos, desde os mundos fantásticos que parecem inibir o regresso de Ulisses, até àqueles que progressivamente o vão aproximando do seu universo humano. Na Ilíada, além de contribuir para um desenho da paisagem de Troia, de resto discreto, este tipo de elemento poético, muito mais limitado, está sobretudo ao serviço da convenção literária, como inspirador de epítetos, símiles e catálogos.

Parece também óbvio, por outro lado, que as descrições homéricas da paisagem ajudam a reconstituir uma imagem da Grécia arcaica, fortemente florestada, e da progressiva intervenção humana sobre essas espécies primitivas, no sentido de extrair delas matérias necessárias ao quotidiano, além do espaço reservado à habitação e à agricultura. Logo, por trás da convenção, os dois poemas não deixam de prestar um interessante contributo para a reconstituição desse mundo arcaico sujeito aos primeiros movimentos evolutivos. É talvez desse equilibrio, entre o que é fantástico e real, que resulta o verdadeiro mérito do poeta chamado Homero, cujos versos constituem, como Teofrasto também reconheceu em matéria botânica, uma fonte de referência.

\section{REFERÊNCIAS}

ASSUNÇÃO, Teodoro R. Lotófagos (Odisseia IX, 82-104): comida floral fácil e risco de desistência. Classica, v. 29, n. 1, p. 273-94, 2016. DoI: https://doi.org/10.24277/classica.v29i1.416

BAUMANN, Hellmut. Le bouquet d'Athéna. Les plantes dans la mythologie et l'art grecs. Trad. Roger Barbier. Paris: Flammarion, 1984.

BOARDMAN, John. Odysseus' travels: real and mythical geography. In: OLIVEIRA, F. (Ed.). Penélope e Ulisses. Coimbra: APEC, IEC, CECH, 2003, p. 25-34.

EDWARDS, Anthony T. Homer's ethical geography: country and city in the Odyssey. Transactions of the American Philological Association, v. 123, p. 27-78, 1993.

HALLER, Benjamin S. Landscape description in Homer's Odyssey. PhD. Pittsburgh: University of Pittsburgh, 2007.

HENDERSON, John. The name of the tree: recounting Odyssey XXIV 340-2. Journal of Hellenic Studies, v. 117, p. 87-116, 1997. 
IRWIN, M. Eleanor. Odysseus' 'hyacinthine hair' in Odyssey 6. 231. Phoenix, v. 44, n. 3, p. 205-18, 1990.

LOURENÇO, Frederico. Homero. Iliada. Lisboa: Cotovia, 2005.

LOURENÇO, Frederico. Homero. Odisseia. Lisboa: Quetzal, 2018.

McINERNEY, Jeremy; SLUITER, Ineke. Valuing landscape in Classical Antiquity. Leiden; Boston: Brill, 2016.

MILES, Margaret. Birds around the temple: constructing a sacred environment. In: McINERNEY, Jeremy; SLUITER, Ineke (Ed.). Valuing landscape in Classical Antiquity. Leiden; Boston: Brill, 2016, p. 151-95.

MOULTON, Carroll. Similes in the Iliad. Hermes, v. 102, n. 3, p. 381-97, 1974.

SEGAL, Charles. The Phaeacians and the symbolism of Odysseus' return. Arion, v. 1, n. 4, p. 17-64, 1962.

STANNARD, Joseph. The plant called moly. Osiris, v. 14, p. 254-307, 1962.

THANOS, Constantinos A. The geography of Theophrastus' life and of his botanical

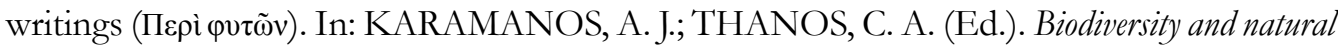
heritage in the Aegean. Proceedings of the conference 'Theophrastus 2000'. Atenas: Frangoudis, 2005, p. 23-45. 